\title{
Proteomic analysis reveals some common proteins in the kidney stone matrix
}

\author{
Yuanyuan Yang ${ }^{1}$, Senyuan Hong ${ }^{1}$, Cong Li ${ }^{1}$, Jiaqiao Zhang ${ }^{1}$, Henglong Hu ${ }^{1}$, Xiaolong Chen ${ }^{2}$, Kehua Jiang ${ }^{2}$, Fa \\ Sun $^{2}$, Qing Wang ${ }^{\text {Corresp., 2, } 3 \text {, Shaogang Wang }}{ }^{\text {Corresp. 1 }}$ \\ 1 Department of Urology, Tongji Hospital, Tongji Medical College, Huazhong University of Science and Technology, wuhan, Hubei, china \\ Department of Urology, Guizhou Provincial People's Hospital, Guizhou University, Guiyang, Guizhou, china \\ 3 Department of Research Laboratory Center, Guizhou Provincial People's Hospital, Guizhou University, Guiyang, Guizhou, china \\ Corresponding Authors: Qing Wang, Shaogang Wang \\ Email address: wangqingtjm@hust.edu.cn, sgwangtjm@163.com
}

Background: Proteins are the most abundant component of kidney stone matrices and their presence may reflect the process of the stone's formation. Many studies have explored the proteomics of urinary stones and crystals. We sought to comprehensively identify the proteins found in kidney stones and to identify new, reliable biomolecules for use in nephrolithiasis research.

Methods: We conducted bioinformatics research in November 2020 on the proteomics of urinary stones and crystals. We used the ClusterProfiler R package to transform proteins into their corresponding genes and Ensembl IDs. In each study we located where proteomic results intersected to determine the 20 most frequently identified stone matrix proteins. We used the Human Protein Atlas to obtain the biological information of the 20 proteins and conducted Gene Ontology (GO) and Kyoto Encyclopedia of Genes and Genome (KEGG) analysis to explore their biological functions. We also performed immunohistochemistry to detect the expression of the top five stone matrix proteins in renal tissue.

Results: We included 19 relevant studies for analysis. We then identified 1,409 proteins in the stone matrix after the duplicates were removed. The 20 most-commonly identified stone matrix proteins were: S100A8, S100A9, uromodulin, albumin, osteopontin, lactotransferrin, vitamin K-dependent protein Z, prothrombin, hemoglobin subunit beta, myeloperoxidase, mannan-binding lectin serine protease 2 , lysozyme C, complement C3, serum amyloid P-component, cathepsin G, vitronectin, apolipoprotein A-1, eosinophil cationic protein, fibrinogen alpha chain, and apolipoprotein D. GO and KEGG analysis revealed that these proteins were typically engaged in inflammation and immune response.Immunohistochemistry of the top five stone matrix proteins in renal tissue showed that the expression of S100A8, S100A9, and osteopontin increased, while uromodulin decreased in kidney stone patients. Albumin was rarely expressed in the kidney with no significant difference between healthy controls and kidney stone patients.

Conclusion: Proteomic analysis revealed some common inflammation-related proteins in the kidney stone matrix. The role of these proteins in stone formation should be explored for their potential use as diagnostic biomarkers and therapeutic targets for urolithiasis. 
1

2 Yuanyuan Yang 1 , Senyuan Hong ${ }^{1}$, Cong $\mathrm{Li}^{1}$, Jiaqiao Zhang ${ }^{1}$, Henglong $\mathrm{Hu}^{1}$, Xiaolong Chen ${ }^{2}$,

3 Kehua Jiang ${ }^{2}, \mathrm{Fa} \mathrm{Sun}^{2}$, Qing Wang ${ }^{2,3 \#}$, Shaogang Wang ${ }^{1 \#}$

4

5 Affiliations:

6 1. Department of Urology, Tongji Hospital, Tongji Medical College, Huazhong University of

7 Science and Technology, Wuhan, Hubei, 430030, China.

8 2. Department of Urology, Guizhou Provincial People's Hospital, Guizhou University, Guiyang,

9 Guizhou, 550000, China.

3. Department of Research Laboratory Center, Guizhou Provincial People's Hospital, Guizhou

Short title: Proteomics of stone matrix.

\section{\# Co-corresponding authors:}

Qing Wang

Email: wangqingtjm@hust.edu.cn

Phone: (+86) 0851- 85924943

\section{Shaogang Wang}

Email: sgwangtjm@163.com

Phone: (+86) 027-83665207

\section{E-mails:}

Yuanyuan Yang: TJyangyuanyuan@163.com

Senyuan Hong: westshane@126.com

Cong Li: licongtjm@163.com 
28 Jiaqiao Zhang: medzjq@163.com

29 Yuchao Lu: luyuchao@hust.edu.cn

30 Henglong Hu: huhenglong@hust.edu.cn

31 Xiaolong Chen: 82273476@qq.com

32 Kehua Jiang: tjjkh@sina.com

33 Fa Sun: sfgme@sina.com

34

35

36

37

38

39

40

41

42

43

44

45

46

47

48

49

50

51

52

53

54

Peer] reviewing PDF | (2021:02:57846:1:0:NEW 20 Jun 2021) 
82 dependent protein Z, prothrombin, hemoglobin subunit beta, myeloperoxidase, mannan-binding

83 lectin serine protease 2, lysozyme C, complement C3, serum amyloid P-component, cathepsin G, 84 vitronectin, apolipoprotein A-1, eosinophil cationic protein, fibrinogen alpha chain, and 85 apolipoprotein D. GO and KEGG analysis revealed that these proteins were typically engaged in 86 inflammation and immune response. Immunohistochemistry of the top five stone matrix proteins 87 in renal tissue showed that the expression of S100A8, S100A9, and osteopontin increased, while 88 uromodulin decreased in kidney stone patients. Albumin was rarely expressed in the kidney with 89 no significant difference between healthy controls and kidney stone patients.

90

91 Conclusion:

92 Proteomic analysis revealed some common inflammation-related proteins in the kidney stone matrix. The role of these proteins in stone formation should be explored for their potential use as

94

95

96

97

98

99

100

101

102

103

104

105

106

107

108 diagnostic biomarkers and therapeutic targets for urolithiasis.

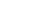

98

99




\section{Introduction}

Kidney stones are a common public health problem. It is estimated that $10 \%$ to $12 \%$ of the general population will suffer from nephrolithiasis in their lifetime ${ }^{[1]}$. The prevalence of kidney stones is currently $6.4 \%$ of the general population in China and this incidence has increased over the past four decades in Western countries [2,3]. The ten-year recurrence rate for kidney stones may be as high as $50 \%$, resulting in repetitive treatments and a huge economic burden ${ }^{[4,5]}$. Thus, it is important to explore the pathogenesis of nephrolithiasis and provide a theoretical basis for its treatment and prevention.

Kidney stones are composed of $97-98 \%$ mineral salts and 2-3\% organic matrix ${ }^{[6]}$. The organic matrix, including proteins, lipids, glycosaminoglycans, and carbohydrates, plays a role in modulating the formation of stones ${ }^{[7]}$. Proteins are the most abundant component in a kidney stone and comprise approximately $64 \%$ of the stone matrix ${ }^{[6]}$. The identification of the matrix proteins contributes to a better understanding of a stone's formation. Advancements in proteomic techniques and the introduction of mass spectrometry have improved the study of the proteomics in urinary stones and crystals ${ }^{[8-26]}$. More than one thousand proteins have been detected in the stone matrix to date. Some common proteins, including S100A8, S100A9, and osteopontin (OPN) are frequently detected in stones and may reveal a potentially universal pattern for stone formation.

135 We conducted a systemic review of studies that focused on the proteomics of the stone matrix 
136

137

138

139

140

141

142

143

144

145

146

147

148

149

150

151

152

153

154

to determine the proteins in kidney stones and to identify those that were the most frequently occuring. We performed bioinformatic analysis to explore the function of the top 20 matrix proteins and immunohistochemistry to detect the expression of the top five stone matrix proteins in renal tissue. We sought to provide new and reliable biomolecules for urolithiasis research.

\section{Methods}

\section{Literature search}

We conducted a systematic literature search of Medline, Embase, and the Web of Science databases in November 2020. The following search strategy was used: (((((urin*) OR kidney) OR renal)) AND (((((stone) OR calculi) OR calcium) OR matrix) OR crystal)) AND proteomic. We included studies that were written in English and associated with proteomics of urinary stones and crystals in our study.

\section{Bioinformatic analysis}

We used clusterProfiler package in $\mathrm{R}$ version 4.0.0 to transform the proteins to related genes and Ensembl IDs ${ }^{[27]}$ to unify the names of proteins in different studies. We took the intersection of the proteomic results from each study and identified the 20 most common stone matrix proteins. We searched the Human Protein Altas to obtain the biological information of the matrix proteins (https://www.proteinatlas.org/) [28]. Gene Ontology (GO) and Kyoto Encyclopedia of Genes and Genome (KEGG) analyses were performed using the OmicShare tool, a free online platform for data analysis (http://www.omicshare.com/tools) to explore the biological function of the 20 proteins. Enrichment results were filtered with a false discovery rate (FDR) of $<0.05$.

\section{Immunohistochemistry}

Renal tissue was collected from patients undergoing nephrectomy due to kidney stones or renal tumor. Tissue from kidney stone patients was classified as the stone group and normal paracancer tissue from kidney tumor patients was defined as the control group. The samples 
163

164

165

166

167

168

169

170

171

172

173

174

175

176

177

178

179

180

181

182

183

184

185

186

187

188

189

were fixed with formalin and embedded in paraffin for routine sectioning. Slices of the tissue were incubated with anti-S100A8 antibody (Abcam, ab92331), anti-S100A9 antibody (Abcam, ab92507), anti-uromodulin antibody (Boster, A01303-2), anti-OPN (Abcam, ab8448), and antialbumin antibody (Abclonal, A1363) for immunohistochemistry. We used Image J software version 1.52 (National Institute of Mental Health) was used to quantify the relative area of the positive staining area. The ethical review board of Tongji Hospital, Tongji Medical College, Huazhong University of Science and Technology approved the collection and use of tissue samples (2019S1147). The written form of informed consent was obtained from all patients.

\section{Statistical Analysis}

Measurement data are presented as mean \pm standard deviations. A Student's t-test was conducted using Prism 9.0 for statistical analysis. A p-value 0.05 was considered to be statistically significant.

\section{Results}

\section{An overview of the included studies}

Figure 1 shows the process used to select studies. We included 19 studies exploring the proteomics of urinary stones and crystals and an overview of these studies is shown in Table 1. Liquid chromatography-tandem mass spectrometry (LC-MS/MS) was the most commonly-used proteomic technique and provided high-throughput amino acid sequence data. Most studies focused on calcium oxalate $(\mathrm{CaOx})$ and uric acid (UA) stones but occasionally rare stone types such as matrix and $\mathrm{CaCO} 3$ stones were also studied. Thurgood et al. also reported the protein files in urinary crystals from a healthy population ${ }^{[13,14]}$. Many common inflammatory proteins were identified in various studies, indicating the involvement of inflammation in stone formation.

Identifying the 20 most common proteins in stone matrices 
190

191

192

193

194

195

196

197

198

199

200

201

202

203

204

205

206

207

208

209

210

211

212

213

214

215

216

The detailed proteomic results of each study are presented in Supplemental File 1. A total of 1,409 proteins were detected in the stone matrix after removing duplicates (Supplemental File 1). We intersected each study to identify the most common stone matrix proteins. The most frequently detected proteins in the stone matrix were: S100A8, S100A9, uromodulin, albumin, OPN, lactotransferrin, vitamin K-dependent protein Z, prothrombin, hemoglobin subunit beta, myeloperoxidase, mannan-binding lectin serine protease 2 , lysozyme $\mathrm{C}$, complement $\mathrm{C} 3$, serum amyloid P-component, cathepsin G, vitronectin, apolipoprotein A-1, eosinophil cationic protein, fibrinogen alpha chain, and apolipoprotein D. Figure 2 shows the exact detection frequency of each protein. We also conducted a subgroup analysis of the studies and focused only on $\mathrm{CaOx}$ stones. We found that the 20 most common proteins in $\mathrm{CaOx}$ stone matrices were same as the above 20 proteins (Supplemental File 2). We searched the online Human Protein Altas database to explore the biology of these proteins. Uromodulin, OPN, lysozyme C, and apolipoprotein D had medium to high expression in renal tubular epithelial cells, while the remaining proteins were rich in other tissues (Table 2).

\section{Biological function of the $\mathbf{2 0}$ most common proteins in stone matrices}

GO annotation showed that the top 20 proteins were involved in the stimulus response, binding activity, and extracellular region. They played a role in the immune response, indicating that stone formation was associated with the inflammatory response. These 20 proteins showed a strong ability to bind with calcium ions, which may explain why they appeared in the stone matrix (Figure 3). KEGG annotation also showed that the top 20 proteins participated in immune and infectious disease responses. They were enriched in the complement and coagulation cascades pathway, which activates the complements involved in the immune response and coagulation cascades associated with inflammation (Figure 4).

\section{The expression of the top five stone matrix proteins in renal tissue}

Among the 20 common stone matrix proteins, S100A8 and S100A9 were the most frequently 
217 detected and they appeared in all kinds of urinary stones. Our previous study demonstrated that 218 urinary exosomes from kidney stone patients were rich in S100A8 and S100A9 [29]. 219 Immunohistochemistry results showed that the expression of S100A8, S100A9 and OPN was 220 significantly increased in renal tissue from kidney stone patients. In contrast, the expression of 221 uromodulin was decreased in the renal tissue of kidney stone patients. Positive S100A8 and 222 S100A9 staining were restricted in cells within vessels in normal kidney tissues. However, 223 S100A8 and S100A9 were mainly expressed in the renal interstitium of kidney stone patients. 224 The expression of OPN and uromodulin typically occured in renal tubular epithelial cells in both 225 the control and stone groups. Albumin was rarely detected in the kidney and there was no 226 significant difference between healthy controls and kidney stone patients(Figure5).

227

228

229

230

231

232

233

234

235

236

237

238

239

240

241

242

243

\section{Discussion}

Stone matrix proteins play a role in modulating the nucleation, aggregation and growth of urinary crystals, which may affect stone formation [30]. Several investigators in the last $20^{\text {th }}$ century attempted to identify the proteins in stones, but were limited by the lack of high throughput technology [31-33]. Thousands of proteins have been identified in the stone matrix with the introduction of mass spectrometry, which has improved the understanding of the pathogenesis of urolithiasis.

The binding of proteins to various stones is selective despite the presence of some common proteins. We identified the 20 most common proteins in the stone matrix. These proteins typically engaged in immune and inflammatory responses, indicating the role of inflammation in stone formation. Recent studies have reported that the macrophage-related immune response participates in stone formation and immunotherapy may be used to treat kidney stone disease ${ }^{[34]}$. Only four of the 20 most common matrix proteins showed medium-to-high expression in the kidney (Table 2). Other non-renal-specific proteins were throught to originate from plasma proteins physiologically filtered through the glomeruli, products of immune cells infiltrated in the renal interstitium, or plasma proteins pathologically exudated due to the injury and infection 
244

245

246

247

248

249

250

251

252

253

254

255

256

257

258

259

260

261

262

263

264

265

266

267

268

269

270

caused by stones.

S100A8 and S100A9 were detected with the highest frequency from the top five matrix proteins. These proteins belong to the S100 calcium binding family and are primarily derived from neutrophils, monocytes and M1 macrophages $[35,36]$. As critical alarmin, S100A8 and S100A9 play an important role in regulating the immune response. They mediate the production of proinflammatory cytokines and the recruitment of leukocytes [37]. New et al. reported that S100A9-rich vesicles from macrophages have a powerful potential for calcification in $2013^{\text {[38] }}$ We previously demonstrated that the expression of urinary exosomal S100A8 and S100A9 in kidney stone patients was higher than in healthy controls ${ }^{[29]}$. In this study, the expression of S100A8 and S100A9 in renal tissue was also found to be elevated in kidney stone patients. In addition, S100A8 and S100A9 were detected in the renal interstitium of kidney stone patients, which may originate from macrophages in the kidney. The potential role of S100A8 and S100A9 in stone formation is worthy of further exploration. They may be valuable as both diagnostic biomarkers and therapeutic targets for urolithiasis.

Uromodulin, also known as Tamm-Horsfall protein (THP), is the third most common stone matrix protein. It is secreted from the thick ascending limb of Henle's loop ${ }^{[39]}$. Previous in vitro studies have shown that THP could inhibit the aggregation of calcium oxalate and calcium phosphate crystals ${ }^{[40]}$. Liu et al. identified crystals deposited in the kidneys of THP knockout mice at as early as two months of age. Transmission electron microscopy showed that the deposits were spherical in shape with multiple layers, which is similar to human calcium oxalate stones ${ }^{[41]}$. THP is thought to play an inhibitory role in stone formation. However, urinary THP excretion decreases in kidney stone patients ${ }^{[42]}$. We also found that the expression of uromodulin decreased in the renal tissue of kidney stone patients. Stone formers have been reported to excrete defective THP, which lacks sialic acid and reducing its effectiveness in inhibiting stone formation ${ }^{[43,44]}$. Increasing the expression of THP and restoring its function may be effective in the prevention of kidney stones.

Albumin is the fourth most common stone matrix protein and it is rarely expressed in the 
271 kidney. The albumin in the stone matrix was thought to originate from plasma proteins filtered 272 through the glomeruli. Albumin is reported to be a powerful nucleator of COD and the polymer 273 form is more active than the monomer form ${ }^{[45]}$. Cerini et al. thought that promotion of COD 274 crystallization by albumin of crystallization mayight be a protective factor for urine stability, 275 because thewith rapid nucleation of small crystals caused the, the saturation levels to fall, 276 preventing COM formation and aggregation with subsequent stone formation be prevented [45].

277 OPN, the fifth most common stone matrix protein, is expressed in the distal renal tubules and 278 thick ascending limbs of Henle's loop ${ }^{[46]}$. The expression of OPN has been shown to increase in 279 the kidneys of stone patients and experimental models, which was validated by our findings [47]. 280 The role of OPN in stone formation remains controversial and may depend on its 281 phosphorylation level ${ }^{[48]}$. Kleinman et al. reported that OPN knockout mice developed more $282 \mathrm{CaOx}$ crystals in their kidney than wild type mice in the hyperoxaluria model [49]. Wesson et al. 283 report edthat OPN favors the formation of calcium oxalate dihydrate (COD) over calcium 284 oxalate monohydrate (COM). COD is less adherent to renal epithelial cells than COM, which 285 may partly explain the antilithiatic effect of OPN ${ }^{[50]}$. However, other studies have shown that 286 OPN may increase the risk of stone formation by promoting crystal adherence to the renal 287 epithelium ${ }^{[51,52]}$.

\section{Conclusions}

290 We identified some common inflammation-related proteins that play a role in stone formation based on proteomic data, to help determine the pathogenesis of human urolithiasis. However, the mere detection of a protein does not explain how it participates in stone formation.

293 Future studies are needed to identify the role of these proteins in stone formation and are expected to provide new diagnostic biomarkers and therapeutic targets for urolithiasis.

\section{List of abbreviations}

297 COM: Calcium oxalate monohydrate 
298 COD: Calcium oxalate dihydrate

299 CaCO3: Calcium carbonate

$300 \mathrm{CaOx}$ : Calcium oxalate

301 CaP: Calcium phosphate

302 FDR: False discovery rate

303 GO: Gene ontology

304 HA: Hydroxyapatite

305 KEGG: Kyoto Encyclopedia of Genes and Genome

306 LC-MS/MS: Liquid chromatography-tandem mass spectrometry

307 MAP: Magnesium ammonium phosphate

308 OPN: Osteopontin

309 THP: Tamm-Horsfall protein

310 UA: Uric acid

311

312

\section{Reference}

313 1. Coe FL, Evan A, Worcester E. Kidney stone disease. J Clin Invest. 2005; 115 (10): 2598-608.

314 2. Zeng GH, Mai ZL, Xia SJ, Wang ZP, Zhang KQ, Wang L, et al. Prevalence of kidney stones 315 in China: an ultrasonography based cross-sectional study. BJU Int. 2017; 120 (1): 109-16.

316 3. Scales CD Jr, Smith AC, Hanley JM, Saigal CS, Urologic Diseases in America Project. 317 Prevalence of kidney stones in the United States. Eur Urol. 2012; 62 (1): 160-5.

318 4. Uribarri J, Oh MS, Carroll HJ. The first kidney stone. Ann Intern Med. 1989; 111 (12): $1006-9$. 319 5. Geraghty RM, Cook P, Walker V, Somani BK. Evaluation of the economic burden of kidney 320 stone disease in the UK: a retrospective cohort study with a mean follow-up of 19 years. BJU Int. $3212020 ; 125$ (4): 586-94.

322 6. Boyce WH. Organic matrix of human urinary concretions. Am J Med. 1968; 45 (5): 673-83.

323 7. Boyce WH, Garvey FK. The amount and nature of the organic matrix in urinary calculi: a 324 review. J Urol. 1956; 76 (3): 213-27. 
325

326

327

328

329

330

331

332

333

334

335

336

337

338

339

340

341

342

343

344

345

346

347

348

349

350

351

8. Mushtaq S, Siddiqui AA, Naqvi ZA, Rattani A, Talati J, Palmberg C, et al. Identification of myeloperoxidase, $\alpha$-defensin and calgranulin in calcium oxalate renal stones. Clin Chim Acta. 2007; 384 (1-2): 41-7.

9. Canales BK, Anderson L, Higgins L, Slaton J, Roberts KP, Liu N, et al. Comprehensive proteomic analysis of human calcium oxalate monohydrate kidney stone matrix. J Endourol. 2008; 22 (6): 1161-7.

10. Merchant ML, Cummins TD, Wilkey DW, Salyer SA, Powell DW, Klein JB, et al. Proteomic analysis of renal calculi indicates an important role for inflammatory processes in calcium stone formation. Am J Physiol Renal Physiol. 2008; 295 (4): F1254-8.

11. Chen WC, Lai CC, Tsai YH, Lin WY, Tsai FJ. Mass spectroscopic characteristics of low molecular weight proteins extracted from calcium oxalate stones: preliminary study. J Clin Lab Anal. 2008; 22 (1): 77-85.

12. Canales BK, Anderson L, Higgins L, Frethem C, Resseler A, Kim IW, et al. Proteomic analysis of a matrix stone: a case report. Urol Res. 2009; 37 (6): 323-9.

13. Thurgood LA, Ryall RL. Proteomic analysis of proteins selectively associated with hydroxyapatite, brushite, and uric acid crystals precipitated from human urine. J Proteome Res. 2010; 9 (10): 5402-12.

14. Thurgood LA, Wang T, Chataway TK, Ryall RL. Comparison of the specific incorporation of intracrystalline proteins into urinary calcium oxalate monohydrate and dihydrate crystals. J Proteome Res. 2010; 9 (9): 4745-57.

15. Canales BK, Anderson L, Higgins L, Ensrud-Bowlin K, Roberts KP, Wu BL, et al. Proteome of human calcium kidney stones. Urology 2010; 76 (4): 1013-20.

16. Kaneko K, Yoshida N, Okazaki K, Yamanobe T, Yamaoka N, Yasuda M, et al. Urinary stone analysis in a patient with hyperuricemia to determine the mechanism of stone formation. Nucleosides Nucleotides Nucleic Acids. 2011; 30 (12): 1072-6.

17. Jou YC, Fang CY, Chen SY, Chen FH, Cheng MC, Shen CH, et al. Proteomic study of renal uric acid stone. Urology. 2012; 80 (2): 260-6. 
352 18. Kaneko K, Kobayashi R, Yasuda M, Izumi Y, Yamanobe T, Shimizu T. Comparison of 353 matrix proteins in different types of urinary stone by proteomic analysis using liquid 354 chromatography-tandem mass spectrometry. Int J Urol. 2012; 19 (8): 765-72.

Diversity in protein profiles of individual calcium oxalate kidney stones. PLoS One. 2013; 8 (7): e68624.

20. Boonla C, Tosukhowong P, Spittau B, Schlosser A, Pimratana C, Krieglstein K. Inflammatory and fibrotic proteins proteomically identified as key protein constituents in urine and stone matrix of patients with kidney calculi. Clin Chim Acta. 2014; 429: 81-9. 21. Kaneko K, Matsuta Y, Moriyama M, Yasuda M, Chishima N, Yamaoka N, et al.

Proteomic analysis of a rare urinary stone composed of calcium carbonate and calcium oxalate dihydrate: a case report. Int J Urol. 2014; 21 (3): 341-6.

22. Kaneko K, Nishii S, Izumi Y, Yasuda M, Yamanobe T, Fukuuchi T, et al. Proteomic Analysis after Sequential Extraction of Matrix Proteins in Urinary Stones Composed of Calcium

23. Martelli C, Marzano V, Iavarone F, Huang L, Vincenzoni F, Desiderio C, et al. Characterization of the Protein Components of Matrix Stones Sheds Light on S100-A8 and S100-A9 Relevance in the Inflammatory Pathogenesis of These Rare Renal Calculi. J Urol. 2016; 196 (3): 911-8.

24. Witzmann FA, Evan AP, Coe FL, Worcester EM, Lingeman JE, Williams JC Jr. Label-free proteomic methodology for the analysis of human kidney stone matrix composition. Proteome Sci. $2016 ; 14: 4$.

25. Kaneko K, Kabeya M, Kondo H, Fukuuchi T, Yamaoka N, Yasuda M, et al. Proteomic analysis of a urinary stone with two layers composed of calcium oxalate monohydrate and uric acid. Nucleosides Nucleotides Nucleic Acids. 2018; 37 (12): 717-23.

26. Wesson JA, Kolbach-Mandel AM, Hoffmann BR. Davis C, Mandel NS. Selective protein enrichment in calcium oxalate stone matrix: a window to pathogenesis? Urolithiasis. 2019; 47 (6): 
379

380

381

382

383

384

385

386

387

388

389

390

391

392

393

394

395

396

397

398

399

400

401

402

403

404

405

521-32.

27. Yu GC, Wang LG, Han YY, He QY. ClusterProfiler: an R package for comparing biological themes among gene clusters. OMICS. 2012; 16 (5): 284-7.

28. Uhlén M, Fagerberg L, Hallström BM, Lindskog C, Oksvold P, Mardinoglu A, et al. Tissuebased map of the human proteome. Science. 2015; 347 (6220): 1260419.

29. Wang Q, Sun Y, Yang YY, Li C, Zhang JQ, Wang SG. Quantitative proteomic analysis of urinary exosomes in kidney stone patients. Transl Androl Urol. 2020; 9 (4): 1572-84.

30. Narula S, Tandon S, Kumar D, Varshney S, Adlakha K, et al. Human kidney stone matrix proteins alleviate hyperoxaluria induced renal stress by targeting cell-crystal interactions. Life Sci. 2020; 262: 118498.

31. Binette JP, Binette MB, Gawinowicz MA, Kendrick N. Urinary stone proteins: an update. Scanning Microsc. 1996; 10 (2): 509-17.

32. Sugimoto T, Funae Y, Rübben H, Nishio S, Hautmann R, Lutzeyer W. Resolution of proteins in the kidney stone matrix using high-performance liquid chromatography. Eur Urol. 1985; $11(5): 334-40$.

33. Jones WT, Resnick MI. The characterization of soluble matrix proteins in selected human renal calculi using two-dimensional polyacrylamide gel electrophoresis. J Urol. 1990; 144 (4): $1010-4$

34. Dominguez-Gutierrez PR, Kwenda EP, Khan SR, Canales BK. Immunotherapy for stone disease. Curr Opin Urol. 2020; 30 (2): 183-9.

35. Pruenster M, Vogl T, Roth J, Sperandio M. S100A8/A9: From basic science to clinical application. Pharmacol Ther. 2016; 167: 120-31.

36. Dessing MC, Tammaro A, Pulskens PW, Teske GJ, Butter LM, Claessen N, et al. The calcium-binding protein complex S100A8/A9 has a crucial role in controlling macrophagemediated renal repair following ischemia/reperfusion. Kidney Int. 2015; 87 (1): 85-94.

37. Wang S, Song R, Wang Z, Jing Z, Wang S, Ma J. S100A8/A9 in Inflammation. Front Immunol. 2018; 9: 1298. 
406

407

408

409

410

411

412

413

414

415

416

417

418

419

420

421

422

423

424

425

426

427

428

429

430

431

432

38. New SE, Goettsch C, Aikawa M, Marchini JF, Shibasaki M, Yabusaki K, et al. Macrophage derived matrix vesicles: an alternative novel mechanism for micro calcification in atherosclerotic plaques. Circ Res. 2013; 113 (1): 72-7.

39. Gokhale JA, Glenton PA, Khan SR. Characterization of Tamm-Horsfall protein in a rat nephrolithiasis model. J Urol. 2001; 166 (4): 1492-7.

40. Kumar V, Lieske JC. Protein regulation of intrarenal crystallization. Curr Opin Nephrol Hypertens. 2006; 15 (4): 374-80.

41. Liu YL, Mo L, Goldfarb DS, Evan AP, Liang F, Khan SR, et al. Progressive renal papillary calcification and ureteral stone formation in mice deficient for Tamm-Horsfall protein. Am J Physiol Renal Physiol. 2010; 299 (3): F469-78.

42. Lau WH, Leong WS, Ismail Z, Gam LH. Qualification and application of an ELISA for the determination of Tamm Horsfall protein (THP) in human urine and its use for screening of kidney stone disease. Int J Biol Sci. 2008; 4 (4): 215-22.

43. Knörle R, Schnierle P, Koch A, Buchholz NP, Hering F, Seiler H, et al. Tamm-Horsfall glycoprotein: role in inhibition and promotion of renal calcium oxalate stone formation studied with Fourier-Transform Infrared spectroscopy. Clin Chem. 1994; 40 (9): 1739-43.

44. Viswanathan R, Rimer JD, Kolbach AM, Ward MD, Kleinman JG, Wesson JA. Calcium oxalate monohydrate aggregation induced by aggregation of desialylated Tamm-Horsfall protein. Urol Res. 2011; 39 (4): 269-82.

45. Cerini C, Geider S, Dussol B, Hennequin C, Daudon M, Veesler S, et al. Nucleation of calcium oxalate crystals by albumin: involvement in the prevention of stone formation. Kidney Int. 1999; 55 (5): 1776-86.

46. Xie Y, Sakatsume M, Nishi S, Narita I, Arakawa M, Gejyo F. Expression, roles, receptors, and regulation of osteopontin in the kidney. Kidney Int. 2001; 60 (5): 1645-57.

47. Kleinman JG, Wesson JA, Hughes J. Osteopontin and calcium stone formation. Nephron Physiol. 2004; 98 (2): p43-7.

48. Wang LJ, Guan XY, Tang RK, Hoyer JR, Wierzbicki A, Yoreo JJD, et al. Phosphorylation of 
433

434

435

436

437

438

439

440

441

442

443

444

445

446

447

448

449

450

451

452

453

454

455

456

457

458

459

osteopontin is required for inhibition of calcium oxalate crystallization. J Phys Chem B. 2008; 112 (30): 9151-7.

49. Wesson JA, Johnson RJ, Marrilda M, Beshensky AM, Stietz S, Giachelli C, et al.

Osteopontin is a critical inhibitor of calcium oxalate crystal formation and retention in renal tubules. J Am Soc Nephrol. 2003; 14 (1): 139-47.

50. Wesson JA, Johnson RJ, Marrilda M, Beshensky AM, Stietz S, Giachelli C, et al. Osteopontin is a critical inhibitor of calcium oxalate crystal formation and retention in renal tubules. J Am Soc Nephrol. 2003; 14 (1): 139-47.

51. Yamate T, Kohri K, Umekawa T, Amasaki N, Amasaki N, Isikawa Y, et al. The effect of osteopontin on the adhesion of calcium oxalate crystals to Madin-Darby canine kidney cells. Eur Urol. 1996; 30 (3): 388-93.

52. Yamate T, Kohri K, Umekawa T, Konya E, Ishikawa Y, Iguchi M, et al. Interaction between osteopontin on madin darby canine kidney cell membrane and calcium oxalate crystal. Urol Int. 1999; 62 (2): 81-6.

\section{Figure legends}

Fig. 1. Flowchart of the literature search and study selection.

Fig. 2. The 20 most common proteins in stone matrix. A. Detection frequency of the top 20 proteins in stone matrix. B. Detection of the top 20 proteins in each study.

Fig. 3. GO analysis of the 20 most common proteins in stone matrix. A. GO annotation. B. GO biological process enrichment analysis. C. GO molecular function enrichment analysis. Rich Factor referred to the ratio of the number of enriched genes in the GO category to the total genes in that category. FDR referred to false discovery rate. FDR $<0.05$ was set as the cut-off value. 
460 Fig. 4. KEGG analysis of the 20 most common proteins in stone matrix. A. KEGG 461 annotation. B. KEGG disease enrichment analysis.

462

463

Fig. 5. Representative images for detection of the top five stone matrix proteins in renal tissue. The renal expression of S100A8, S100A9, and osteopontin were increased, while 465 uromodulin was decreased in kidney stone patients. Albumin was rarely expressed in kidney and 466 there was no significant difference between healthy controls and kidney stone patients. 


\section{Table 1 (on next page)}

Basic information of included studies

Detailed information of the 19 studies we included in our research. 


\begin{tabular}{|c|c|c|c|c|c|c|c|}
\hline Years & Authors & $\begin{array}{c}\text { Sample } \\
\text { Size } \\
\end{array}$ & $\begin{array}{c}\text { Stone } \\
\text { composition }\end{array}$ & $\begin{array}{l}\text { Proteomic } \\
\text { technique }\end{array}$ & $\begin{array}{c}\text { Verification } \\
\text { methods }\end{array}$ & $\begin{array}{c}\text { Proteins } \\
\text { identified }\end{array}$ & Main findings \\
\hline $2007^{[8]}$ & Mushtaq et al. & 40 & $\mathrm{CaOx}$ & $\begin{array}{l}\text { 1D PAGE } \\
\text { LC-MS/MS }\end{array}$ & Western blot & 4 & $\begin{array}{l}\text { Myeloperoxidase, } \alpha \text {-defensin and } \\
\text { calgranulin were identified from inner } \\
\text { core of } \mathrm{CaOx} \text { stones and they promoted } \\
\text { the aggregation of } \mathrm{CaOx} \text { crystals. } \\
\text { Osteopontin was detected both in the } \\
\text { inner and outer matrix of } \mathrm{CaOx} \text { stones. }\end{array}$ \\
\hline $2008^{[9]}$ & Canales et al. & 7 & $\mathrm{CaOx}$ & LC-MS/MS & NA & 68 & $\begin{array}{l}\text { A significant number of inflammatory } \\
\text { proteins, such as immunoglobulin, } \alpha- \\
\text { defensin-3, clusterin, complement } \mathrm{C} 3 \mathrm{a} \text {, } \\
\text { kininogen, calgranulin and fibrinogen, } \\
\text { were found in } \mathrm{CaOx} \text { stones matrix. }\end{array}$ \\
\hline $2008^{[10]}$ & Merchant et al. & 4 & $\mathrm{CaOx}$ & LC-MS/MS & Western blot & 158 & $\begin{array}{l}58 \text { prevalent proteins were detected in at } \\
\text { least two of the three LC-MS/MS } \\
\text { analyses. Pathway analysis suggested that } \\
\text { a significant fraction of } \mathrm{CaOx} \text { stone } \\
\text { matrix proteins participate in } \\
\text { inflammatory processes. }\end{array}$ \\
\hline $2008^{[11]}$ & Chen et al. & 10 & $\mathrm{CaOx}$ & $\begin{array}{l}\text { 1D PAGE } \\
\text { LC-MS/MS }\end{array}$ & NA & 11 & $\begin{array}{l}\text { There were abundant proteins with } \\
\text { molecular weight around } 27 \mathrm{kDa}, 14 \mathrm{kDa} \text {, } \\
\text { and } 10 \mathrm{kDa} \text { in } \mathrm{CaOx} \text { stones matrix. } \\
\text { Methylation, deamidation, and oxidation } \\
\text { were indentified with mass spectroscopy } \\
\text { in these proteins. }\end{array}$ \\
\hline $2009^{[12]}$ & Canales et al. & 1 & Matrix stone & LC-MS/MS & NA & 33 & $\begin{array}{l}\text { Protein file of matrix stones included } \\
\text { many similar inflammatory proteins seen } \\
\text { in previous proteomic studies of } \mathrm{CaOx}\end{array}$ \\
\hline
\end{tabular}




\begin{tabular}{|c|c|c|c|c|c|c|c|}
\hline & & & & & & & $\begin{array}{l}\text { stone matrix, indicating a primary } \\
\text { inflammatory mechanism behind matrix } \\
\text { stones. }\end{array}$ \\
\hline \multirow[t]{3}{*}{$2010^{[13]}$} & Thurgood et al.\# & 5 & HA & LC-MS/MS & NA & 36 & \multirow{3}{*}{$\begin{array}{l}\text { Binding of proteins to urinary } \\
\text { hydroxyapatite, brushite, and uric acid } \\
\text { crystals is selective and distinct. Several } \\
\text { proteins consistently detected in the } \\
\text { healthy urine crystal extracts, such as } \\
\text { osteopontin, prothrombin and S100A9, } \\
\text { have been previously implicated in kidney } \\
\text { stone disease. }\end{array}$} \\
\hline & & & Brushite & LC-MS/MS & NA & 65 & \\
\hline & & & UA & LC-MS/MS & NA & 7 & \\
\hline $2010^{[14]}$ & Thurgood et al. ${ }^{\#}$ & 5 & $\mathrm{COM}$ & LC-MS/MS & $\begin{array}{c}\text { 2D SDS- } \\
\text { PAGE }\end{array}$ & 14 & \multirow{2}{*}{ 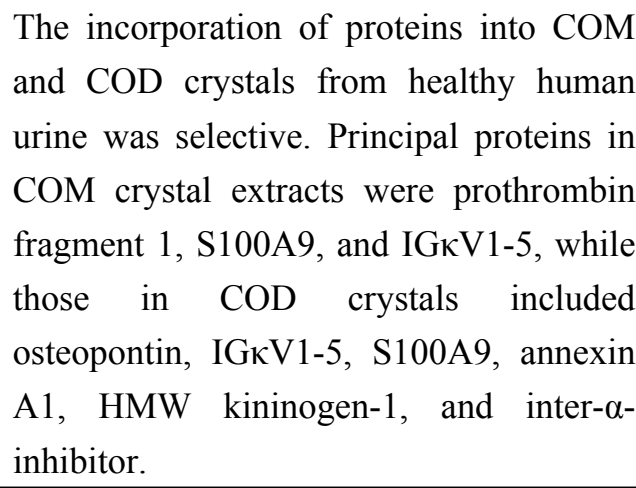 } \\
\hline & & & COD & LC-MS/MS & NA & 34 & \\
\hline \multirow[t]{2}{*}{$2010^{[15]}$} & Canales et al. & 13 & $\mathrm{CaOx}$ & LC-MS/MS & NA & 49 & \multirow{2}{*}{$\begin{array}{l}\mathrm{CaOx} \text { and } \mathrm{CaP} \text { stones shared similar } \\
\text { matrix proteins associated with } \\
\text { inflammatory response, indicating that } \\
\text { inflammation play an important role in } \\
\text { calcium stone formation, no matter as an } \\
\text { origin role or a secondary response. }\end{array}$} \\
\hline & & 12 & $\mathrm{CaP}$ & LC-MS/MS & NA & 45 & \\
\hline $2011^{[16]}$ & Kaneko et al. & 1 & $\mathrm{UA}, \mathrm{COM}$ & LC-MS/MS & NA & 32 & $\begin{array}{l}\text { Calcium-binding proteins, such as } \\
\text { calprotectin, psoriasin, calprotectin and so } \\
\text { on, were identified in stones from patients }\end{array}$ \\
\hline
\end{tabular}




\begin{tabular}{|c|c|c|c|c|c|c|c|}
\hline & & & & & & & $\begin{array}{l}\text { with hyperuricemia. They may play a } \\
\text { significant role in the formation of kidney } \\
\text { uric acid stones. }\end{array}$ \\
\hline $2012^{[17]}$ & Jou et al. & 5 & UA & LC-MS/MS & Western blot & 242 & $\begin{array}{l}\text { The function of proteins identified from } \\
\text { uric acid stones is mainly engaged in } \\
\text { inflammatory process and lipid } \\
\text { metabolism, implying a possible relation } \\
\text { between lipotoxicity and stone formation. }\end{array}$ \\
\hline $2012^{[18]}$ & Kaneko et al. & 17 & $\mathrm{CaOx}, \mathrm{UA}$ & $\begin{array}{c}\text { 1D PAGE } \\
\text { LC-MS/MS }\end{array}$ & Western blot & 30 & $\begin{array}{l}\text { Uromodulin and albumin are often } \\
\text { detected in stones. Osteopontin, } \\
\text { prothrombin, protein } \mathrm{S} \text { and protein } \mathrm{Z} \text { are } \\
\text { identified specifically in calcium oxalate } \\
\text { stones. Immunoglobin } \mathrm{G} \text { fragments are } \\
\text { detected in uric acid stones. }\end{array}$ \\
\hline $2013^{[19]}$ & Okumura et al. & 9 & $\mathrm{CaOx}$ & LC-MS/MS & Western blot & 92 & $\begin{array}{l}\text { Prothrombin, osteopontin, S100A8 and } \\
\text { S100A9 were found in most stones, some } \\
\text { samples had high contents of prothrombin } \\
\text { and osteopontin, while others had high } \\
\text { contents of calgranulins and neutrophil- } \\
\text { enriched proteins. }\end{array}$ \\
\hline $2014[20]$ & Boonla et al. & 16 & $\begin{array}{l}\text { COM, UA, } \\
\text { MAP }\end{array}$ & $\begin{array}{c}\text { 1D PAGE } \\
\text { LC-MS/MS }\end{array}$ & Western blot & 62 & $\begin{array}{l}\text { Kidney stones greatly contained } \\
\text { inflammatory and fibrotic proteins, } \\
\text { indicating that inflammation and fibrosis } \\
\text { are involved in the formation of stones. } \\
\text { S100A8 and fibronectin were the most } \\
\text { abundant protein in stone matrix. }\end{array}$ \\
\hline $2014[21]$ & Kaneko et al. & 1 & $\begin{array}{c}\mathrm{CaCO} 3 \\
\mathrm{CaOx}\end{array}$ & $\begin{array}{c}\text { 1D PAGE } \\
\text { LC-MS/MS }\end{array}$ & NA & 53 & $\begin{array}{l}\text { Matrix proteins from calcium carbonate } \\
\text { stone are mostly associated with cell } \\
\text { adhesion and cytoskeleton. These }\end{array}$ \\
\hline
\end{tabular}




\begin{tabular}{|c|c|c|c|c|c|c|c|}
\hline & & & & & & & $\begin{array}{l}\text { identified proteins may play an important } \\
\text { role on urolithiasis in alkaline condition. }\end{array}$ \\
\hline $2015^{[22]}$ & Kaneko et al. & 16 & $\begin{array}{c}\text { COM, COD, } \\
\text { HA }\end{array}$ & $\begin{array}{l}\text { 1D PAGE } \\
\text { LC-MS/MS }\end{array}$ & NA & 65 & $\begin{array}{l}\text { Many plasma proteins were frequently } \\
\text { detected in stone matrix regardless of the } \\
\text { stone components. Identified proteins } \\
\text { were involved in inflammation, } \\
\text { coagulation process, and } \\
\text { osteometabolism. }\end{array}$ \\
\hline $2016^{[23]}$ & Martelli et al. & 4 & Matrix stone & $\begin{array}{l}\text { 1D PAGE } \\
\text { LC-MS/MS }\end{array}$ & NA & 142 & $\begin{array}{l}\text { S100A8, S100A9 and neutrophil defensin } \\
\text { were identified as the main component of } \\
\text { matrix stones. Inflammatory process may } \\
\text { be the origin of this kind of rare soft } \\
\text { calculi formation but not be the } \\
\text { consequence. }\end{array}$ \\
\hline $2016^{[24]}$ & Witzmann et al. & 2 & $\mathrm{CaOx}$ & LC-MS/MS & NA & 1059 & $\begin{array}{l}\text { A more complex stone matrix proteome } \\
\text { than previously studies was reported. } \\
\text { Matrix proteins were related to immune } \\
\text { response, inflammation, injury, and tissue } \\
\text { repair. }\end{array}$ \\
\hline $2018^{[25]}$ & Kaneko et al. & 1 & COM, UA & $\begin{array}{l}\text { 1D PAGE } \\
\text { LC-MS/MS }\end{array}$ & NA & 59 & $\begin{array}{l}\text { Proteins relevant to cell adhesion, self- } \\
\text { defense, and plasma commonly play a } \\
\text { major role in the generation of stone. The } \\
\text { proteins in the interface likely function to } \\
\text { enlarge the stone via the addition of } \\
\text { different crystals. }\end{array}$ \\
\hline $2019^{[26]}$ & Wesson et al. & 8 & $\mathrm{CaOx}$ & LC-MS/MS & NA & 366 & $\begin{array}{l}\text { Osteopontin, mannan-binding lectin serine } \\
\text { protease } 2 \text {, vitamin K-dependent protein } \\
Z \text {, prothrombin, and hemoglobin } \beta \text { chain } \\
\text { were prominently enriched in matrix, }\end{array}$ \\
\hline
\end{tabular}




\begin{tabular}{|l|l|l|l|l|}
\hline & & & $\begin{array}{l}\text { accounting for a mass fraction of }>30 \% \text { of } \\
\text { matrix protein. Many identified matrix } \\
\text { proteins are reported in intracellular or } \\
\text { nuclear locations, indicating a significant } \\
\text { role of cell injury in stone formation. }\end{array}$ \\
\hline \# Crystals are isolated from the urine of healthy people without urinary stones. \\
COM: Calcium oxalate monohydrate \\
COD: Calcium oxalate dihydrate \\
CaCO3: Calcium carbonate \\
CaOx: Calcium oxalate \\
CaP: Calcium phosphate \\
UA: Uric acid \\
MAP: Magnesium ammonium phosphate \\
HA: Hydroxyapatite
\end{tabular}


Table 2 (on next page)

Biological information of the 20 most common proteins in stone matrix

Biological information of the 20 most common proteins in stone matrix (from the Human Protein Altas) 


\begin{tabular}{|c|c|c|c|c|c|c|}
\hline Proteins & GENE & $\begin{array}{c}\text { Tissue } \\
\text { specificity }\end{array}$ & Blood specificity & $\begin{array}{c}\text { Expression } \\
\text { in glomeruli }\end{array}$ & $\begin{array}{c}\text { Expression } \\
\text { in renal } \\
\text { tubules } \\
\end{array}$ & Biological process \\
\hline S100A8 & S100A8 & $\begin{array}{l}\text { Blood, bone } \\
\text { marrow, } \\
\text { esophagus, } \\
\text { tongue }\end{array}$ & Neutrophil, classical monocyte & Rare & Rare & $\begin{array}{c}\text { Apoptosis, autophagy, chemotaxis, } \\
\text { immunity, inflammatory response, } \\
\text { innate immunity }\end{array}$ \\
\hline S100A9 & S100A9 & $\begin{array}{l}\text { Blood, bone } \\
\text { marrow, } \\
\text { esophagus, } \\
\text { tongue }\end{array}$ & Neutrophil, classical monocyte & Rare & Rare & $\begin{array}{c}\text { Apoptosis, autophagy, chemotaxis, } \\
\text { immunity, inflammatory response, } \\
\text { innate immunity }\end{array}$ \\
\hline Uromodulin & UMOD & Kidney & None & Rare & High & $\begin{array}{c}\text { Ciliopathy, disease mutation, } \\
\text { nephronophthisis }\end{array}$ \\
\hline Lactotransferrin & LTF & $\begin{array}{l}\text { Bone marrow, } \\
\text { salivary gland, } \\
\text { seminal vesicle }\end{array}$ & $\begin{array}{c}\text { Non-classical monocyte, } \\
\text { neutrophil }\end{array}$ & Rare & Rare & $\begin{array}{l}\text { Immunity, ion transport, osteogenesis, } \\
\text { iron transport, transcription, } \\
\text { transcription regulation, transport }\end{array}$ \\
\hline $\begin{array}{l}\text { Vitamin } \mathrm{K}- \\
\text { dependent } \\
\text { protein } \mathrm{Z}\end{array}$ & PROZ & Liver & Intermediate monocyte, T-reg & Rare & Rare & Blood coagulation, hemostasis \\
\hline Prothrombin & F2 & Liver & None & Rare & Rare & $\begin{array}{c}\text { Acute phase, blood coagulation, } \\
\text { hemostasis }\end{array}$ \\
\hline $\begin{array}{l}\text { Hemoglobin } \\
\text { subunit beta }\end{array}$ & HBB & Bone marrow & Neutrophil, plasmacytoid DC & Rare & Rare & Oxygen transport, transport \\
\hline
\end{tabular}




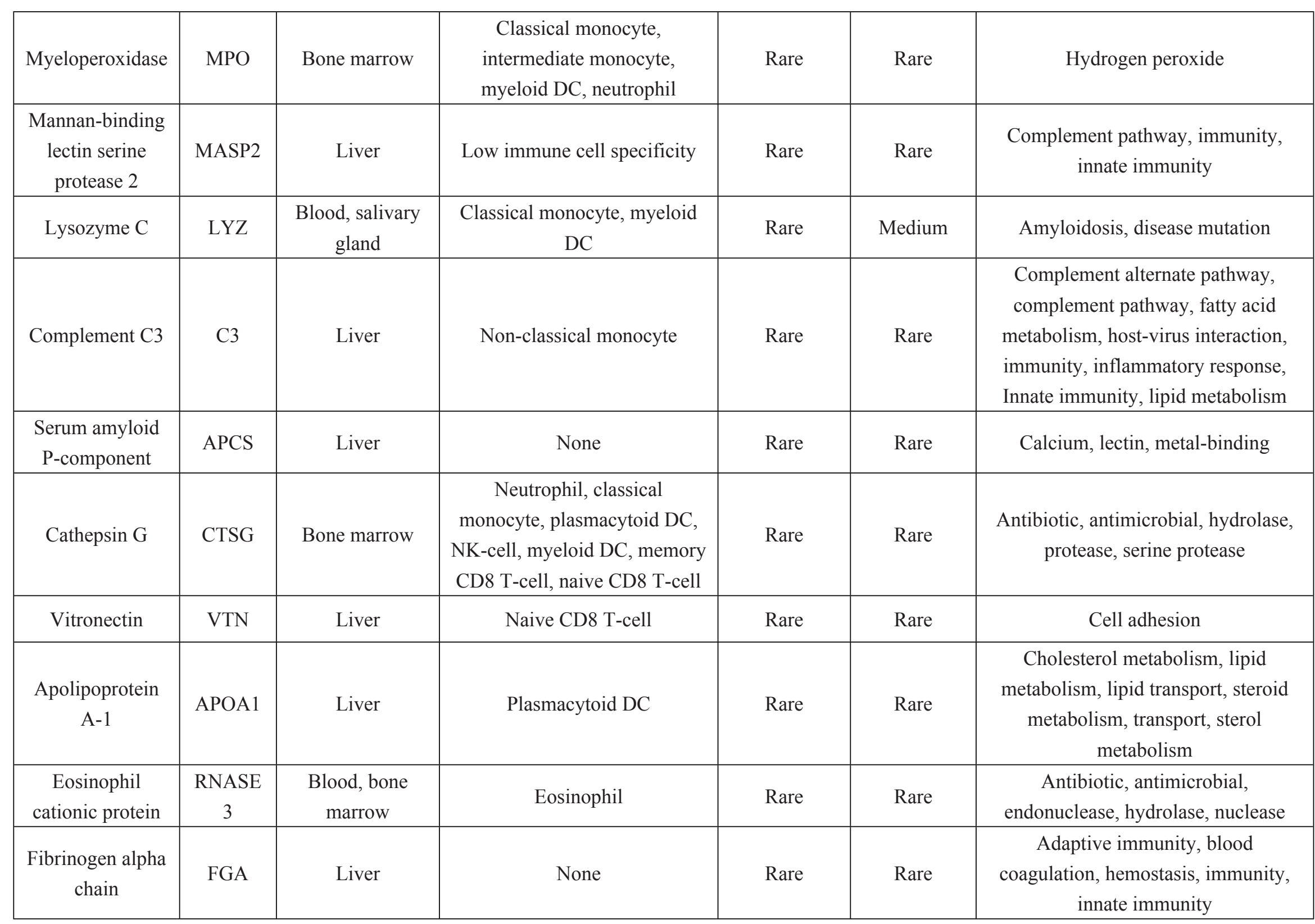




\begin{tabular}{|c|c|c|c|c|c|c|}
\hline $\begin{array}{c}\text { Apolipoprotein } \\
\text { D }\end{array}$ & APOD & Breast & Memory B-cell & Rare & High & Transport \\
\hline
\end{tabular}


Figure 1

Flowchart of the literature search and study selection

Flowchart of the literature search and study selection

Records identified through

PubMed $(n=850)$ Web of Science $(n=1164)$ Embase $(n=1415)$

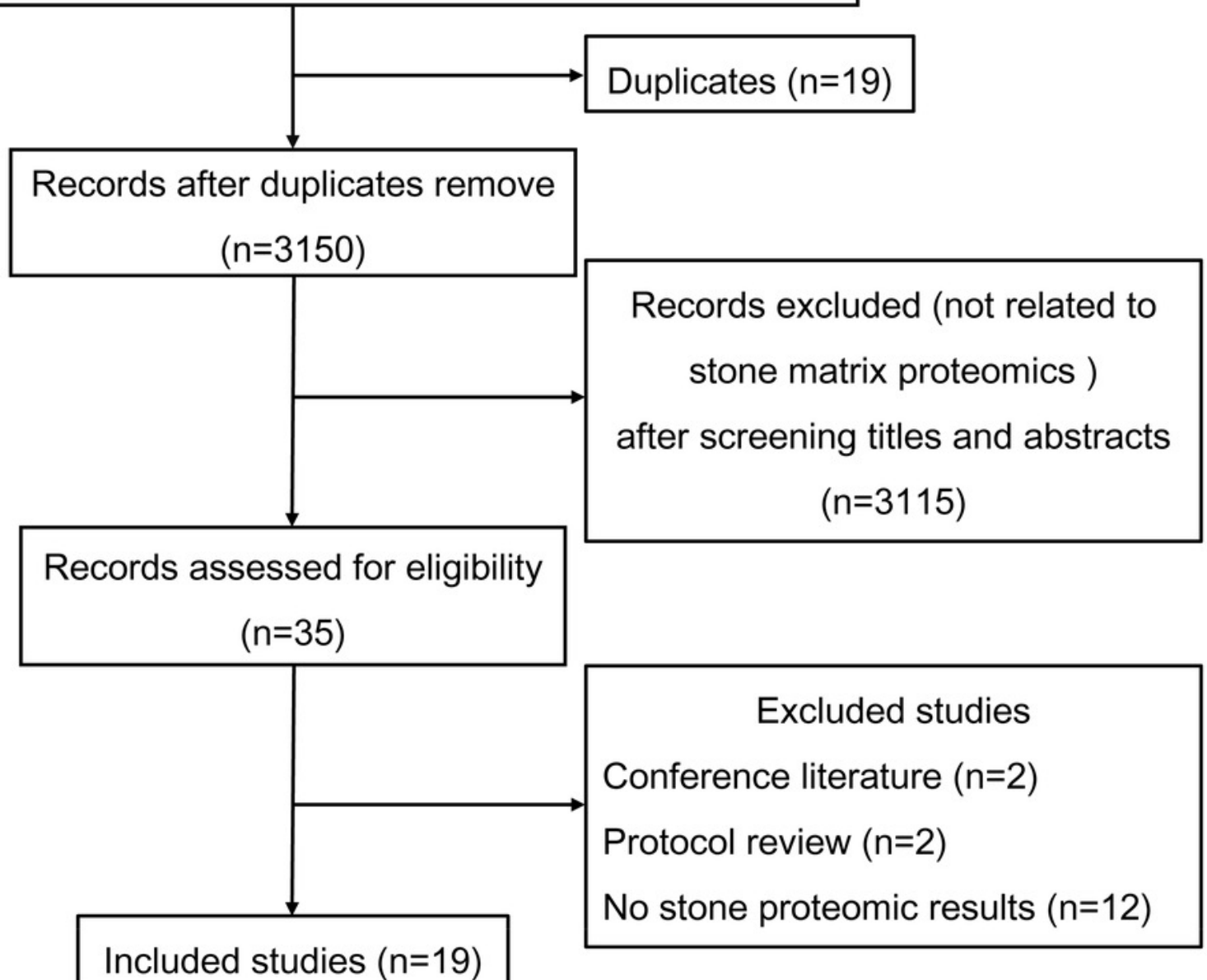


Figure 2

The 20 most common proteins in stone matrix.

A. Detected frequency of the top 20 proteins in stone matrix. B. Detection of the top 20 proteins in each study. 
A

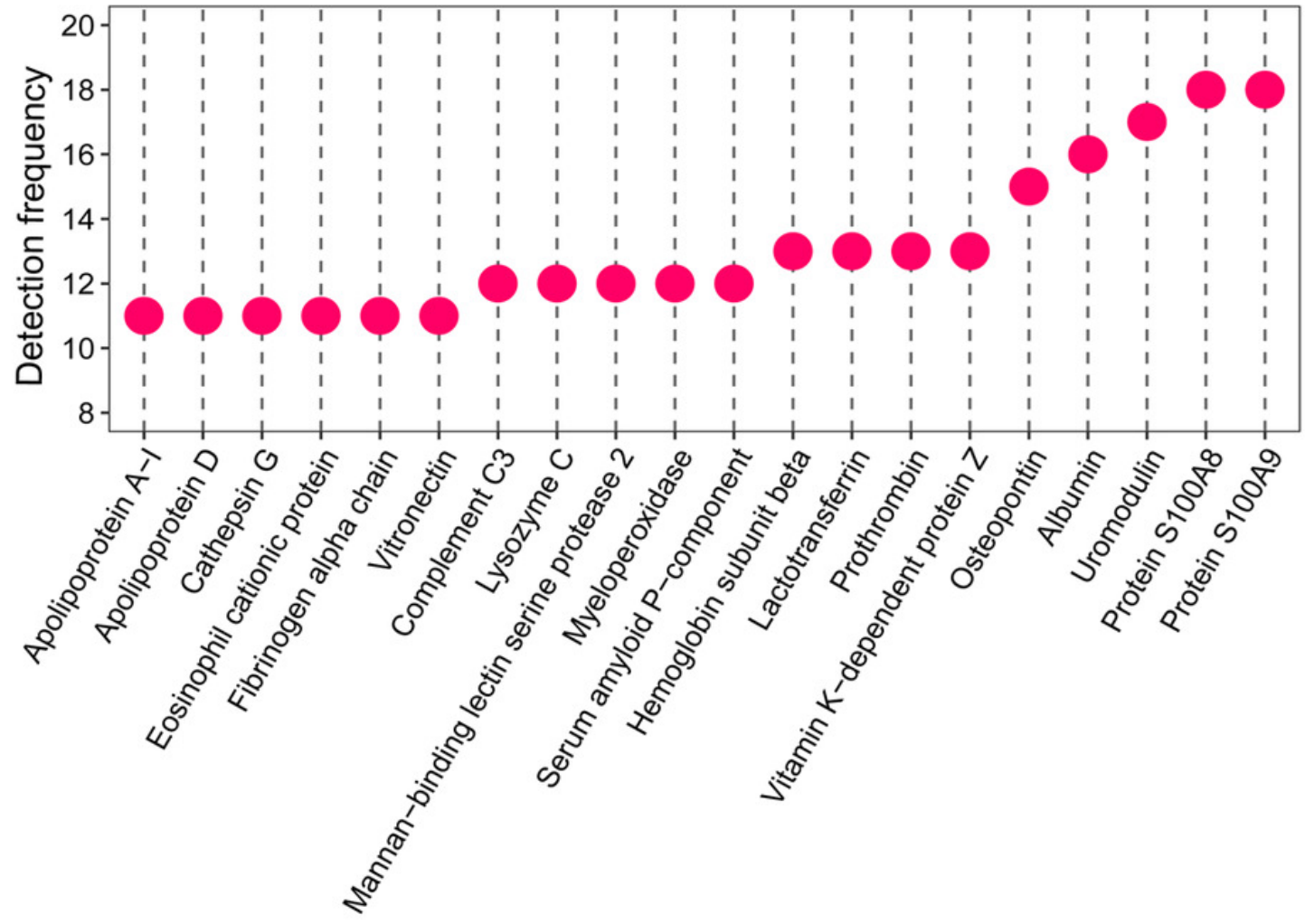

B

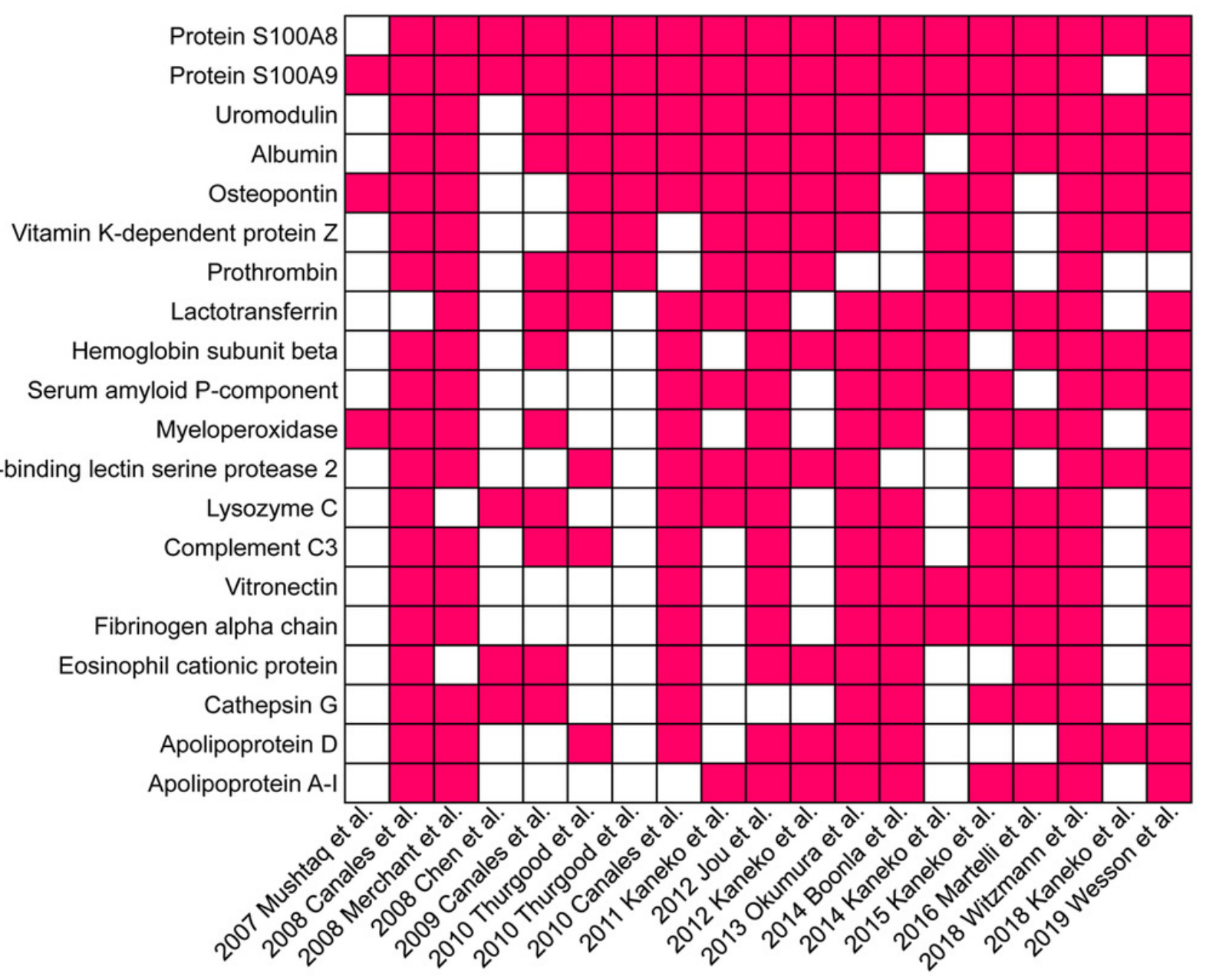


Figure 3

GO analysis of the 20 most common proteins in stone matrix.

A. GO annotation. B. GO biological process enrichment analysis. C. GO molecular function enrichment analysis.C. GO molecular function enrichment analysis. Rich Factor referred to the ratio of the number of enriched genes in the GO category to the total genes in that category. FDR referred to false discovery rate. FDR $<0.05$ was set as the cut-off value. 
A
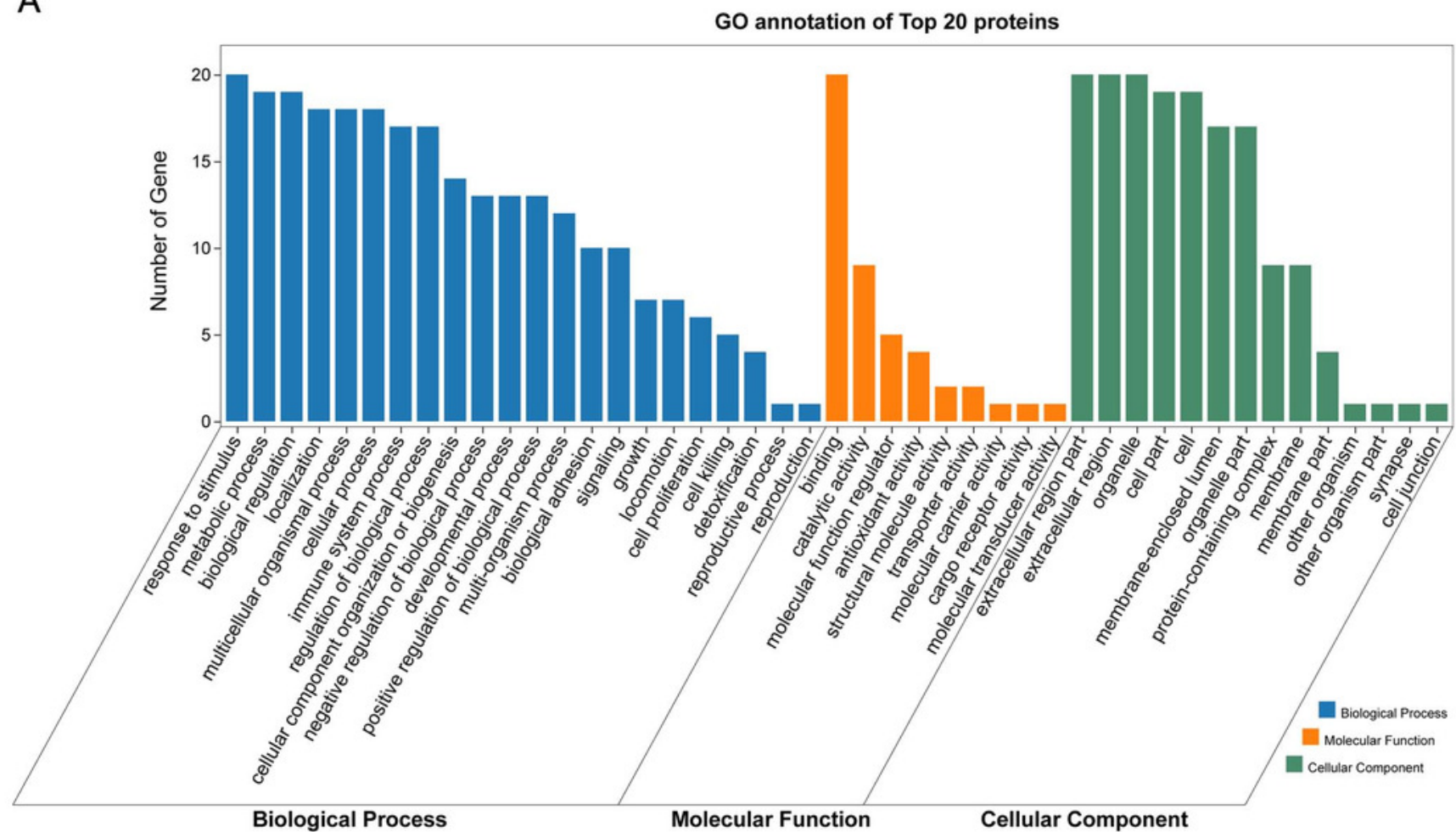

B

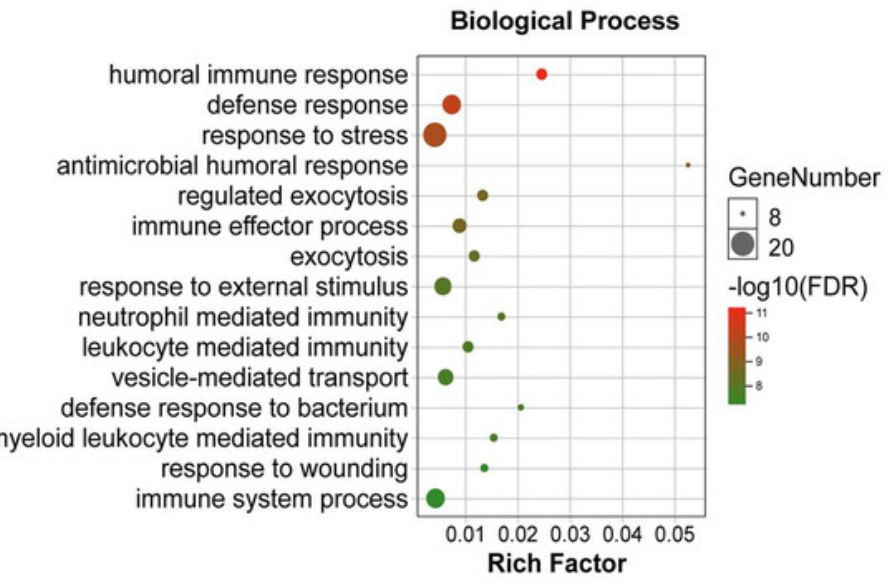

C

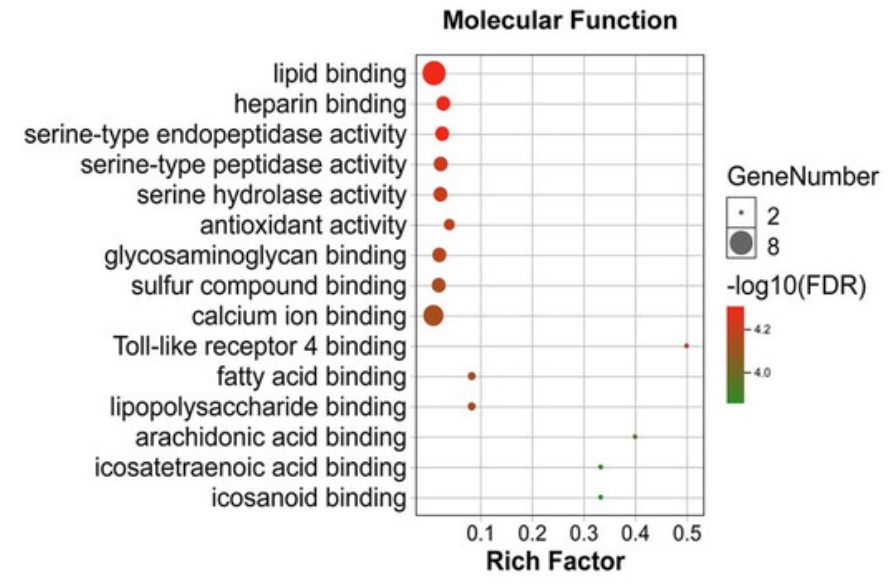


Figure 4

KEGG analysis of the 20 most common proteins in stone matrix.

A. KEGG annotation. B. KEGG disease enrichment analysis.

A

KEGG pathway annotation of Top 20 proteins

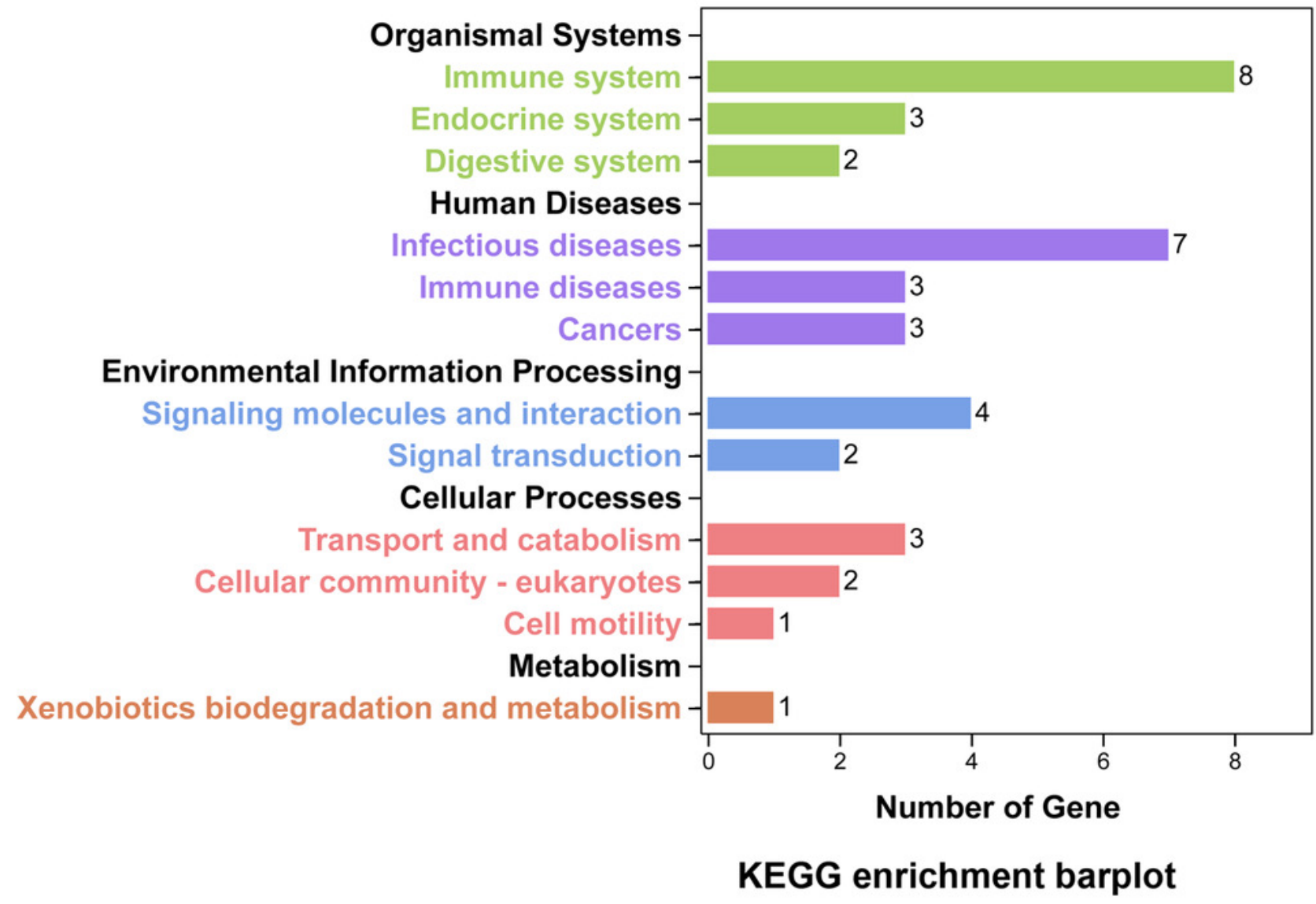

Complement and coagulation cascades African trypanosomiasis -

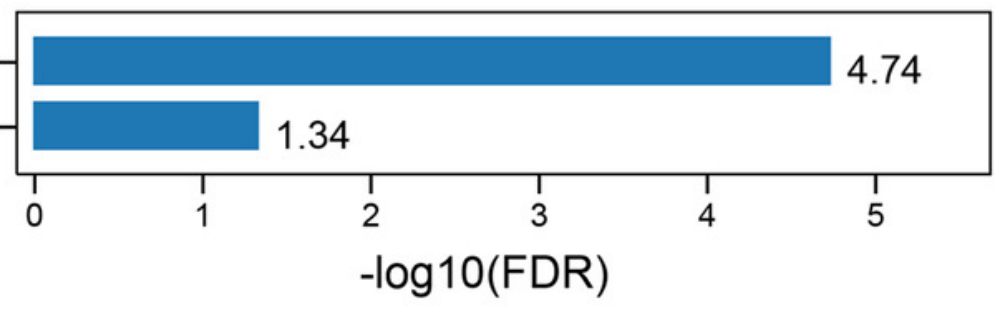




\section{Figure 5}

Representative images for detection of the top five stone matrix proteins in renal tissue.

The renal expression of S100A8, S100A9, and osteopontin were increased, while uromodulin was decreased in kidney stone patients. Albumin was rarely expressed in kidney and there was no significant difference between healthy controls and kidney stone patients. 


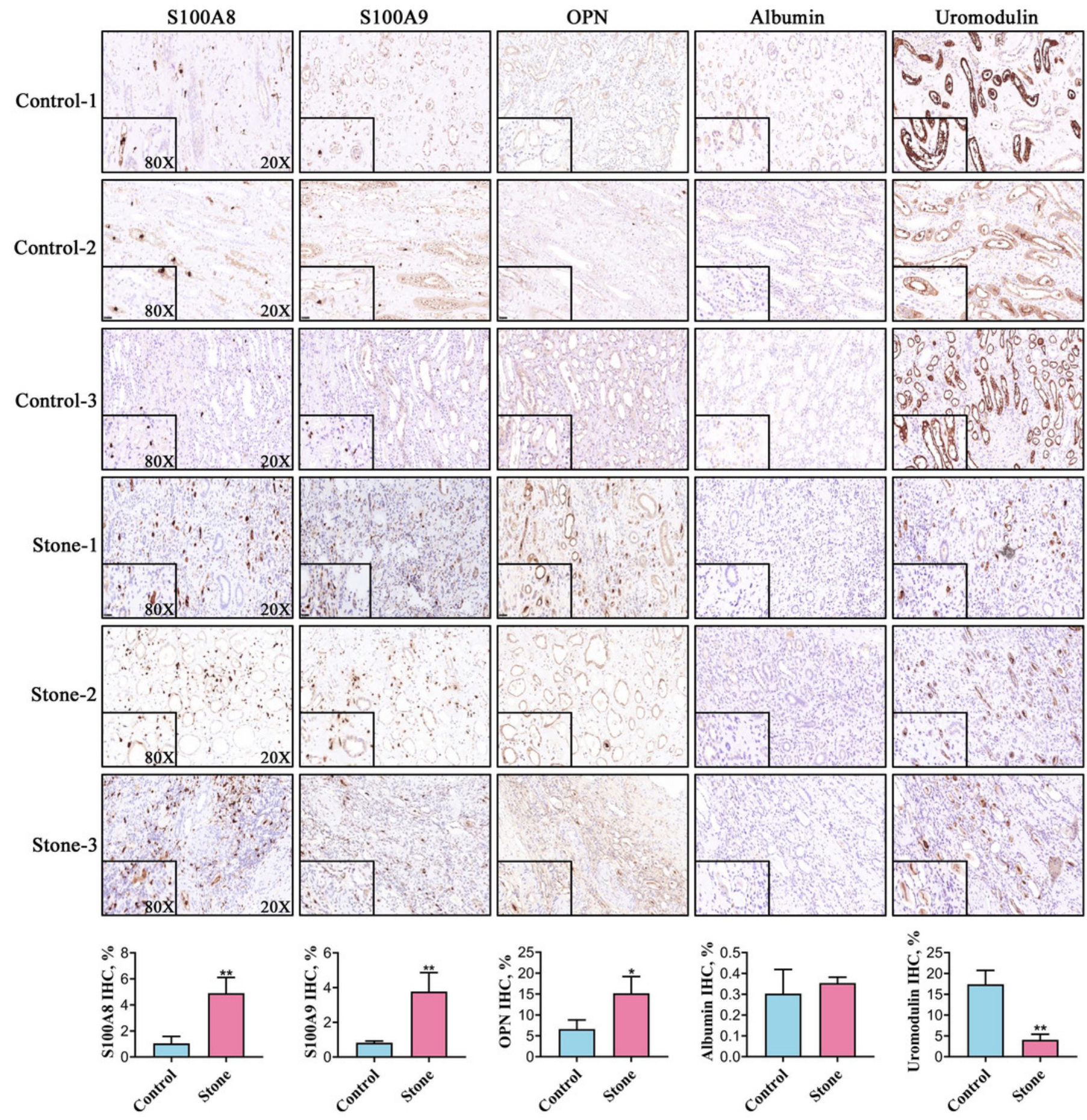

